\title{
5
}

\section{Class, Union or Party Allegiance? Comparing Pension Reform Preferences in Britain and Germany}

\author{
Bernhard Ebbinghaus and Elias Naumann
}

\section{Introduction}

While European welfare states have come under increasing economic and political pressure of welfare state retrenchment and restructuring, the "new politics” approach (Pierson, 2001b) has pointed at several reasons why welfare states “persist” (Brooks and Manza, 2008). In addition to veto points in the political system, two important arguments can be seen in the popularity of social policies among the electorate and the "vested" interests of societal interest groups, particularly trade unions (Ebbinghaus, 2010). Public opinion and organized interests are seen as major obstacles to changing the status quo of social policies such as reforming pay-as-yougo pension systems (Myles and Pierson, 2001). The "blame avoidance” thesis (Weaver, 1986; Bonoli, 2012) assumes that radical retrenchment is politically risky for governments as governing parties in favour of such reforms might suffer from electoral backlash and may meet opposition from influential interest groups and even face political strikes. In our chapter we seek to revisit the "new politics” thesis (Pierson, 2001b) in respect to the role of organized interests and public opinion in both hampering and facilitating pension reform. Our analysis will explore to what degree public opinion defend the status quo and the circumstances under which there is support for reforms. We also explore whether attitudes can be explained by particular institutional variations in pension systems or in party and interest organization systems. We therefore analyse pension-specific attitudes along two 
major dimensions, retrenchment and redistribution, using public opinion data from the 2008 European Social Survey. We compare two countries with different pension systems, organized interests, and party systems: Britain and Germany.

Although international analyses of public opinion show that welfare states in general and pensions in particular are rather popular, there are some sections of the electorate that are more open to reform than others. Nevertheless, generational conflicts are not as pronounced as often assumed in public and academic debates. In some cases, the attitudes of trade union members are not as different from those of other working people, although trade unions often take on more defensive positions, while other interest groups are more open to reforms. Our results show pronounced cross-national differences in pension-specific attitudes toward redistribution. Political affiliations show also more variation than social classes, indicating that ideological alignment are more pronounced than social class or material self-interest.

\section{Explaining retrenchment and redistribution preferences}

At the core of the argument of "why welfare states persist" (Brooks and Manza, 2008) is their “popularity”, assuming a positive feedback of past social policies on potential beneficiaries that leads to status quo interests. In respect to attitudes towards welfare policies, these may also be driven by major values about society’s overall goals and fundamental moral considerations, for example whether a society should aim at equality and equity, respectively. However, empirical studies provide ample evidence that different aspects of welfare policies cannot be summarized into single dimensions such as state versus market and redistribution versus liberalism. Accordingly, researchers have commonly distinguished welfare states along multiple dimensions, such as extensity (or range) of public intervention and intensity (or degree) of social security and equality (Roller, 1995), decommodification and stratification 
(Esping-Andersen, 1990), or benefit levels and eligibility (Bonoli and Natali, 2012). In line with these studies, we propose that attitudes are structured along several more or less independent (orthogonal) dimensions. In our analysis we focus on two of several dimensions relevant for current reform processes: on support for redistribution and opposition to retrenchment.

In general, different theoretical paradigms have been used to contrast normative and rational explanations. Preferences derive from (rational) self-interests based on social position (calculus) or are found to be shaped by value-orientation (culture) embedded in institutional and societal contexts (Wendt et al., 2011). In public opinion surveys, responses to social policy items may reflect an individual's political and moral view of how society "should be" or reflect a respondent's considerations on whether an item is of personal advantage (or selfinterests).

\section{How self-interest and values shape attitudes}

The main rationalist approach to explain redistribution attitudes builds on the "MeltzerRichard” model, which assumes that preferences are driven by material self-interest (Meltzer and Richards, 1981). Accordingly, we would assume that redistribution preferences are determined by the socio-economic position of the individual: High-income earners oppose redistribution as "net payers", whereas people with low income as the beneficiaries (netreceivers) of redistribution should favour redistribution. The same argument applies to pension-specific redistribution. Those groups within society that expect to accumulate less pension claims (as a combination of income, contributions, residence or employment years) should be more inclined towards redistribution and support that pensions should not be strictly linked to contributions but include minimum income protection (means-tested or basic pension). We thus expect that those with higher income will be less in favour of redistribution than those with lower income. 
The normative paradigm would suggest that redistribution is institutionalized in societal norms of justice or reciprocity (Mau, 2004) and embodied in social policy arrangement (Larsen, 2008). Most prominently, such a redistribution goal is inherent in T.H. Marshall's “social citizenship rights” (1950) or the concept of decommodification (Esping-Andersen, 1990): Individuals receive a (pension) benefit independent of their (previous) market income. In addition, studies on attitudes towards pensions reveal more subtle differences amongst pension systems and also test the thesis of generational conflicts between earlier and later cohorts that are differentially affected by pension reforms (Gelissen, 2001; Lynch and Myrskylä, 2009; Fernández and Jaime-Castillo, 2013). We expect the pension system to have a strong effect on the preference formation of all social groups, but particularly for those welfare groups that are dependent on the pension system for old age income. Since retirees are a heterogeneous group with different retirement income situation based on their past working lives (Ebbinghaus and Neugschwender, 2011), it is less clear to predict their attitude towards redistribution. We expect that those with lower-than-average pension benefits should be in favour of redistribution. As the retired are less taxed than the working population, they may also favour redistribution in order to maintain their public pensions. Institutional differences between pension systems will thus matter concerning how particular social groups perceive their preferences.

We make a similar political economy argument concerning opposition to or support for retrenchment. We expect that high-income earners who pay higher taxes and contributions favour retrenchment since they would benefit most from decreasing taxes because their dependency from public benefits is smaller (particularly due to private means) than is that of the lower income groups. In contrast, high-income earners are more likely to have additional private pension-savings, making them less dependent on public pensions (Ebbinghaus and Neugschwender, 2011). 


\section{Post-industrial risk profiles and attitudes}

Although previous research has shown that socio-economic determinants of attitudes are related to self-interest, the rational choice approach misses two important aspects which seem to be very important in the political reform process. First, the studies rather capture the immediate material self-interest but miss future (labour market) risks or opportunities which might have already been anticipated by respondents when forming their attitudes. Second, income groups but also age groups are by and large social groups in itself, although they might not collectively act as an interest group for themselves. Therefore these social or demographic groups often have much less political relevance as they do not actively pursue their interests in the reform process.

Social classes instead are assumed to capture both actual and future interests of their members and these interests are actively advocated by their interest groups. In order to study the effect of social cleavages on pension-specific attitudes we follow the literature on post-industrial risk profiles and adopt a new class schema (Kitschelt and Rehm, 2006; Oesch, 2006). Our interest in reform positions among different social classes rests upon the "new politics" thesis' claim that the politics of reform in times of austerity are different to the politics of welfare state expansion (Pierson, 2001b). This may also hold for reasons of changes in the social structure: The “old” social cleavages, in particular the class conflict between capital and labour (Korpi, 1983), is seen as no longer dominant in today’s society given the tertiarization of labour markets, educational expansion, and growing female employment (Pierson 2001a). The “old” vertical, industrial class structure distinguishing the highly-skilled middle-class from the low-skilled working-class has become more fragmented through the development of a “new” horizontal, post-industrial cleavage (Oesch, 2006). So far, however, it has been difficult to compare "old” and "new” social cleavages empirically, a problem that has been ameliorated by Kitschelt and Rehm (2006) who, by using Oesch’s (2006) fifteen social classes, demonstrated the presence of five larger clusters. Social classes can now be arranged 
according to two of the most influential new dimensions of risk profiles that complement former social class concepts: skill specificity (Iversen and Soskice, 2001) and insider-outsider labour market status (Rueda, 2005). Several empirical contributions have shown that these new post-industrial classes differ in their risk profile (Schwander and Häusermann, 2013), have distinct political interests and preferences (Kitschelt and Rehm, 2006), identify with different parties and interest organizations, and are represented in the political process by different actors (Häusermann, 2010).

Empirical tests of this new class schema show that the post-industrial classes represent valid “short-cuts” for capturing socio-economic groups with specific risk-profiles (Oesch and Rodriguez Menés, 2011). The vertical dimension related to skill-levels and education determines life chances, material advantages, and income, whereas the horizontal dimension divides these groups into those working in stable, highly protected jobs (for example with unlimited contracts) that grant social rights and benefits (capital accumulators and blue-collar workers) and those “outsider” occupations that instead offer part-time employment, limited contracts, and only limited social benefits. In our analysis, we link the horizontal segmentation with the concept of labour market "insiders" and "outsiders" because this distinction reflects the fragmentation of risk profiles within the traditional classes quite well (Häusermann, 2010).

\section{[FIGURE 5.1 ABOUT HERE]}

The post-industrial class schema has been restricted to the working population thus excluding retirees. Nevertheless, a political economy explanation of reforms would remain incomplete without including retirees as their impact on pension reforms is well known (Walker, 1999). Following Lepsius’ concept, we therefore add retirees to our analysis (Figure 5.1) as a 
"welfare class" (Versorgungsklasse), that is a group which depends on the welfare state (Alber, 1984).

\section{The institutional variations}

In general, we expect to confirm previous research and find congruence between public opinion and the existing institutional characteristics of pension systems, particularly those concerning Bismarck vs. Beveridge and public vs. multipillar structures (Ebbinghaus, 2011). However, the positioning of social groups may vary due to the particular pension system. In Bismarckian public pension systems with earnings-related pensions, high-income earners have reasons to oppose retrenchment of pension rights since they have already contributed substantially in the expectation of receiving higher pensions. Due to these accumulated social rights, they may have the strongest interest in defending the status quo, in particular the equivalence principle of Bismarckian earnings-related benefits. The difference between social groups within the working population should thus be less pronounced for pension-specific retrenchment support compared with general cutbacks. In contrast to redistribution preferences, we expect differences between retirees’ and the working population's preference for retrenchment. Since most retirees actually receive public pensions, we expect them to oppose retrenchment of their current pension benefits and instead be in favour of raising contributions (or debt) to finance these benefits.

Britain’s Beveridgean basic pension and multipillar pension system gives state responsibility a larger role for poverty reduction in contrast to the German Bismarckian earnings-related pension system that favours adequate living standard maintenance in old age. Hence, the support for income redistribution in Beveridgean pension systems should be strongest in Britain due to the country's flat-rate basic pensions for all citizens and residents. Moreover, we assume that people have a strong preference for the state's responsibility to provide at least minimum income and oppose retrenchment of already rather meagre basic benefits. In 
contrast, Germany’s relatively generous contribution-based and status-maintaining pension system should have created a stronger preference for income-oriented pensions and only limited redistribution as well as a lower reluctance to retrench these pension benefits given the earned social rights under a pay-as-you-go system (Myles and Pierson 2001).

Our analysis aims to move beyond these general country differences in public support for pension arrangements. In respect to pension policy, the current working population considers pension policy in respect to its past, current and future social risk. Given the earnings-related Bismarckian pension system, those "outsiders" with atypical employment face lower pensions than others (Hinrichs and Jessula 2012), while in Beveridgean system the public flat-rate system provides more of minimum income protection to all citizens (Marshall 1950) in old age (even though contributory non-state pensions increase inequalities). Moreover, we test the degree to which there are differences between those working and those in retirement, given the different interests in maintaining the current status quo versus an orientation towards its future financial sustainability. However, while claims for a generational conflict have been made in public and academic discourse, few studies have managed to establish strong age- or cohort-related differences.

\section{Data and Attitude Measures}

\section{Survey data}

Individual level data for this analysis come from the European Social Survey (ESS) module on welfare attitudes, fielded in 2008/2009. We restrict the sample to respondents from Germany and Great Britain, after deleting cases with missing values (in a list-wise manner) 4,362 respondents were included (Germany: 2,239; Britain: 2,123). For our analysis, respondents of working age (15-65) who participate in the labour market are categorized into one of the five classes according to their occupation (based on ISCO-88 classification). 
Retired people (either age 65 and older or already inactive) are added as a sixth social class, the welfare dependent group. ${ }^{1}$ We distinguish union members from non-union members for all five active social classes, though we report in the following only the aggregate values for the average union member. In order to map the clientele of political parties, we use partyidentification of respondents for the main political parties with more than 5 per cent of the vote in national elections (3 British and 5 German parties), and we report the aggregate value for the average non-voter. Moreover, we compare attitudes by gender and four age groups (age 15-30, 31-50, 51-65 and 65+).

\section{Attitudes towards pension policy: Dependent variables}

To analyse whether or not people support redistributive pensions, we use the following policy-specific item that provides two different views: 'Higher earners should get larger old age pensions because they have paid in more' and the opposite view 'Lower earners should get larger old age pensions because their needs are greater’. Respondents then had to choose one of three statements (on a card) that come closest to their view: 'Lower earners should get larger pensions', 'High and low earners should get the same pensions', and 'Higher earners should get larger pensions' ${ }^{2}$ In order to analyse the dimension of vertical redistribution, we combine the first two answer categories into one ("supporting redistribution"), while the last response is defined as “opposition to redistribution” from better off to less well off. Note that only vertical social redistribution but not temporal (cohorts) or categorical (like gender) redistribution is captured by these items although these are typical for pay-as-you-go public pension systems.

In order to capture the second dimension of retrenchment we use the following common survey item. Respondents were asked whether it should or should not be the "government's responsibility” to ensure a reasonable standard of living for the old. Answer categories ranged from 0 ('not government's responsibility at all') to 10 ('entirely government's 
responsibility'). We reverse the order of the scale so that high values, chosen by respondents who do not find it the government's responsibility to ensure a reasonable standard of living for the old, indicate potential support for retrenchment relative to the current status quo.

\section{Studying British and German Attitudes}

The support for vertical redistribution is largest among British respondents (83 per cent), while in Germany, less than a third (31 per cent) support redistribution either by favouring larger pensions for low earners or a flat-rate pension for everyone (Table 5.1). Germans are much more inclined to oppose redistribution given the strong equivalence principle underlying their Bismarckian public pension, whereas the Beveridgean basic pension philosophy is still dominant among British respondents. In Britain, both redistributive options receive support and a majority of people are in favour of a (moderately) redistributive flat-rate pension for all (65 per cent) than of a highly redistributive larger (means-tested) pension for low earners (18 per cent). A similar difference is found in Germany where only very few respondents would support a highly redistributive pension system (7 per cent). Thus the largest support grouping in each country is in line with the institutional legacy of the Bismarckian and Beveridgean pension system respectively.

\section{[TABLE 5.1 ABOUT HERE]}

Table 5.2 provides results on attitudes towards retrenchment and shows the share across response categories and the country means, indicating that the distribution is skewed to the left. In line with previous research, we find that pensions are (together with healthcare, see Chapter 9 and 10) among the most popular areas of the welfare state. Most people see a very 
high responsibility to ensure a reasonable standard of living for the old regardless of their country: 96 per cent of British and 83 per cent of German respondents consider it the government's responsibility to ensure a reasonable standard of living for the old. Only a very small share of respondents (2 per cent in Britain, 8 per cent in Germany) sees no or limited government responsibility and presumably support a decrease of spending in the case of pensions. The status quo (the middle position on the scale) is only favoured by a small group in Britain (2 per cent) and Germany (9 per cent) in the case of pensions. Thus, support of pension retrenchment or of the status quo is very small. Years of public debate on the need to reform pension systems due to ageing have not led to a pro-retrenchment position. Nevertheless, we can detect a slight tendency of German respondents to be less in favour of government's responsibility on average. Given that British pension reforms have considerably cut back on state pensions, this position might be understandable.

\section{[TABLE 5.2 ABOUT HERE]}

Gender differences are a common finding in studies on welfare attitudes (Blekesaune and Quadagno, 2003; Edlund, 1999; Svallfors, 1997). They are more likely to be employed by the welfare state (Sainsbury, 1996). As women, on average, earn less than men, they are more likely to rely on the welfare state, in particular as single parents during working lives or as widows during retirement. Another explanation put forward, for example by Arts and Gelissen (2001), is that women hold different values than men, favouring equality and need over the equity or merit principle. For these reasons, more than men, women are commonly assumed to support the welfare state in general and redistribution in particular. This gender gap is partly confirmed by our results (see Table 5.3). We find significant gender differences in Britain and Germany for pension-specific attitudes: women show a stronger opposition against retrenchment of pension benefits compared to men. Moreover, German women are 
more likely to favour redistribution through pensions compared to German men, while there is no significant differences among British respondents.

\section{[TABLE 5.3 ABOUT HERE]}

The hypothesis of emerging conflicts between generations, which gained attention in society, shows rather inconclusive findings: some studies report significant age differences (Blekesaune \& Quadagno 2003; Busemeyer et al., 2009: Linos and West 2003), whereas others find no consistent impact of age on welfare state attitudes (Andress and Heien, 2001; Arts and Gelissen, 2001; Jaeger, 2006). One reason for the inconclusive findings might be that welfare states cover very different social policies which are directed at different stages in the life course. Whereas the young age groups (and younger cohorts) mainly benefit from educational and family policy, the older age groups (and older cohorts) mainly depend on pension and health care. Self-interests thus do not lead to clear expectations on whether young or old respondents should have a stronger interest in redistribution or retrenchment.

Moreover, “other regarding” preferences but also long-term self-interests are important factors in attitude formation (Naumann et al., 2015). Young people might support the pension system out of fairness or reciprocity and because they expect to be retirees eventually. Still these values might change from one generation to the next resulting in generational differences in welfare attitudes.

Although we find differences between age groups, in particular in Britain, no clear attitude pattern emerges across all countries (Table 5.3). In line with the self-interest expectation, support for retrenchment is considerably lower among British older respondents. In contrast, no significant differences between age groups can be found in Germany despite the public debate on financial sustainability of the pay-as-you-go public pensions in an ageing society. In Table 5.3 we also show the differences in the predicted probabilities to support 
redistribution via the pension system and compare the different age groups with the youngest age cohort. Young people are more in favour of redistribution (thus less in favour of achievement orientation) in Germany, whereas in Britain old people are the strongest supporters of redistribution (basic pension principle). This could be interpreted that young German respondents expect needing a minimum income given more precarious employment prospects, while in Britain current old age poverty is more of a concern among the older age group.

\section{Mapping pension-specific attitudes two dimensional policy space}

Since we are interested in comparing the positions of distinct social groups that potentially have particular interests and are the potential clientele of interest organizations and political parties, we use multivariate models to estimate the positions of these groups. We estimate logit models for the binary dependent variable and linear regressions for the dependent variable measured on an 11-point scale for each country separately. We therefore estimate whether certain groups (social classes, union members, retirees) significantly differ from each other in their support for retrenchment and redistribution (controlling for age and gender). Based on these regression models, we then predict the probability (estimate the position) for a “typical” member of each group (with mean age and the predominant gender of the respective class) to support redistribution and retrenchment. Values for the redistribution variable range from 0 to 1 . Zero indicates no support for redistribution since no one within the class favours redistribution, whereas 1 indicates very strong support with all members of the class favouring redistribution. Values for the retrenchment measure can range from 0 to 10 , with higher values indicating stronger support for retrenchment. In our analysis, we combine support for redistribution and support for retrenchment in order to map a two-dimensional 
policy space. Assuming the multidimensionality of welfare attitudes, we are particularly interested in whether and how social groups differ in respect to these two dimensions of policy support (Figure 5.2).

\section{[FIGURE 5.2 ABOUT HERE]}

\section{Post-industrial class-cleavages and non/union membership}

The positioning of the British and German population regarding pension policy differs considerably. The largest differences can be seen with respect to support for redistribution (see Figure 5.2). German respondents are much less inclined towards a redistributive pension system compared with British respondents. Regarding support for retrenchment of pensions, state involvement is less popular in Germany in comparison to Britain where we find a strong preference for state involvement. We link these differences with the strong effect of the existing pension systems and the dominance of the German Bismarckian earnings-related social insurance tradition and a British Beverdigean basic pension for all residents, which is, however, not sufficient to eradicate poverty.

In the case of pension attitudes, the within-country differences across social groups are much less pronounced compared to what is usually found in the literature on general welfare attitudes. There are few significant differences in Germany (upper panel in Figure 5.2): Capital accumulators and retirees differ from the average position by being more in favour of retrenchment and least in favour of state involvement, while blue-collar and lower service workers as well as union members tend to be slightly more inclined towards state involvement, and both groups of workers are also in favour of more redistribution. In the case of Britain, there are no particular social differences from the average in pension policy, which shows a remarkable similarity of positions among the British population independent of social class, retirement status, and union membership. The institutional pension context seems to 
have, after years of retrenchment and privatization, led to a rather uni sono positioning towards support of redistribution (in line with the Beveridgean basic pension) and high support for state involvement.

\section{Political allegiance by electoral groups}

In order to understand the political allegiance, we finally analyse the electorate by focussing on the same two-dimensional policy space (lower panel of Figure 5.2). We report party preferences of respondents for the largest parties (being supported by more than 5 per cent of voters) and the position of non-voters. The results for party electorates differ more significantly than for the social classes and union-membership, indicating that party affiliations address important ideological differences that are not congruent with social-class differences. Moreover, we find the same overall cross-national variations in the positioning on the redistribution and retrenchment positions with more pronounced differences in party affiliations in Germany than in Britain.

In Germany, the party positions differ between the conservative pole (FDP: Liberals, CDU: Christian Democrats, including Bavarian sister CSU), which demonstrates a higher preference for retrenchment and less support for redistribution than the average voter, while the redgreen pole (SPD: Social Democrats, Grüne: Green party) and most extremely the far left (Linke) as well as the non-voters favour retrenchment least and redistribution most. The position of the two conservative parties is in line with the capital accumulators and retirees, while the red-green parties are closer to the position of the average respondent. The Linke is somewhat closer to the blue-collar and union-member position. These political differences have made it difficult for the Grand Coalition government of Christian-Democrats and Social Democrats (since 2009) to go beyond gradual pension reforms increasing the retirement age and some concessions for current retirees or those soon retiring. 
In Great Britain (right lower panel in Figure 5.2), the positions of the party supporters are as closely located as in respect to the social classes, a pattern that stands in stark contrast to the big ideological divide in respect to general welfare value-orientation reported in the literature. Concerning pension-specific retrenchment and redistribution attitudes, the British electorate strongly supports the redistributive basic pension and opposes any (further) retrenchment. British political parties will thus find it difficult to develop ideologically different alternatives in pension reform given such similar support among their electorate for the current system and large demand for state involvement. In fact, since the pension act of 2008, several British governments of different partisan composition have maintained the aim of strengthening the public pension and extending supplementary pensions via automatic enrolment.

\section{Conclusion}

Mapping pension-specific attitudes in a two-dimensional policy-space capturing attitudes towards retrenchment and redistribution has revealed some striking cross-national differences between Britain and Germany. In line with institutional differences our analysis shows stronger cross-national differences in respect to the principle of redistribution, and somewhat more limited differences in respect to retrenchment. The German population seems to tend slightly more towards retrenchment than the British. As for redistributive elements in the pensions system, the main difference was found to be in line with the Bismarckian vs. Beveridgean pension system traditions, with Germany representing the achievement-oriented social insurance and Britain the poverty-oriented basic pension policy.

Our study also confirms the existence of attitude differences between social and political groups. Whereas the position of the social classes and non/union membership is much less pronounced than assumed in the literature, party polarization is strongest in Germany on both 
dimensions, and much less observable in Britain. Compared with the strong country effects, social and party polarization effects turn out to be rather small due to the overall popularity of pension policy and rather limited support for retrenchment. Different age groups also agree on such a consensus in favour of the status quo. We do not find strong evidence for a generational conflict over the scope of pension policy, although German younger people buy less into the equivalence principle than older workers, while in Britain support for redistribution increases with age.

Our analysis thus suggests that old-age is rather perceived as a life course and not a labour market related risk (Jensen, 2012) which explains that everyone has an interest in being protected and supported in old age irrespective of income or social class. Such strong support for pensions is reinforced by the high deservingness of the elderly. Both aspects contribute to our finding of high support and little conflict over pension policies between social and political groups. Under these circumstances, it is very likely that left- and right-wing governments enact similar policies and that only gradual re-calibration of the pension system along the basic principles of the existing pension institutions will occur.

Nevertheless, it remains an interesting question for future research how stable strong support and little conflict over pension policies is. External shocks like financial crises but also population ageing which slowly erodes the financial sustainability of the pension system might affect pension attitudes and reform preferences (see also Chapter 8). Moreover, political ideology determines how people react to increasing reform pressures (Brooks and Manza, 2013; Jensen and Naumann, 2016) and conflict lines might emerge as a consequence. This suggests that political parties but also unions might play an important role in the political economy of reforms by framing how financial crises and population ageing affect individual interests and reform preferences. 


\section{Notes}

${ }^{1}$ We exclude respondents still in education and do not split up retirees into early retired and "regularly” retired people. The rate of early retirement before age 65 is high for women in Britain (normal retirement at age 60, but 65 for men), and medium-high but declining for men and women in Germany (phased-in increases in pre-retirement since the mid-1990s).

${ }^{2} 2.6$ per cent of the respondents chose a fourth answer 'none of these'. We ignore this as a negligible percentage of respondents by analysing these responses as missing.

\section{References}

Alber, J. (1984) 'Versorgungsklassen im Wohlfahrtsstaat', Kölner Zeitschrift für Soziologie und Sozialpsychologie, 36, 225-251.

Andreß, H. and T. Heien (2001) 'Four worlds of welfare state attitudes? A comparison of Germany, Norway, and the United States‘, European Sociological Review, 17, 4, 337-356. Arts, W. and J. Gelissen (2001) 'Welfare states, solidarity and justice principles. Does the type really matter?‘, Acta Sociologica, 44, 4, 283-299.

Blekesaune, M. and J. Quadagno (2003) 'Public attitudes toward welfare state policies. A comparative analysis of 24 nations‘, European Sociological Review, 19, 5, 415-427.

Bonoli, G. and D. Natali (eds.) (2012) The politics of the new welfare state (Oxford: Oxford University Press).

Brooks, C. and J. Manza (2008) Why welfare states persist. The importance of public opinion in democracies (Chicago: University of Chicago Press). 
Brooks, C. and J. Manza (2013) 'A broken public? Americans’ response‘ to the great recession‘, American Sociological Review, 78, 5, 727-748.

Busemeyer, M. R., A. Goerres and S. Weschle (2009) ‘Attitudes towards redistributive spending in an era of demographic ageing. The rival pressures from age and income in 14 OECD countries ‘, Journal of European Social Policy, 19, 3, 195-212.

Ebbinghaus, B. (ed.) (2011) Varieties of pension governance. The privatization of pensions in Europe (Oxford: Oxford University Press).

Ebbinghaus, B. (2010) 'Unions and employers‘ in F. G. Castles, S. Leibfried, J. Lewis, H. Obinger, C. Pierson (eds.) The Oxford handbook of the welfare state (Oxford: Oxford University Press).

Ebbinghaus, B. and J. Neugschwender (2011) 'The Public-Private Pension Mix and Old Age Income Inequality‘ in B. Ebbinghaus (ed.) Varieties of pension governance. The privatization of pensions in Europe (Oxford: Oxford University Press).

Edlund, J. (1999) 'Trust in government and welfare regimes. Attitudes to redistribution and financial cheating in the USA and Norway', European Journal of Political Research, 35, 3, $341-370$.

Esping-Andersen, G. (1990) The three worlds of welfare capitalism (Princeton: Princeton University Press).

Fernandez, J. J. and A. M. Jaime-Castillo (2013) 'Positive or negative policy feedbacks? Explaining popular attitudes towards pragmatic pension policy reforms‘, European Sociological Review, 29, 4, 803-815.

Gelissen, J. (2001) 'Old-age pensions. Individual or collective responsibility? An investigation of public opinion across European welfare states', European Societies, 3, 4, 495-523.

Häusermann, S. (2010) The politics of welfare state reform in continental Europe. Modernization in hard times (Cambridge: Cambridge University Press). 
Hinrichs, K. and M. Jessoula (2012) Labour market flexibility and pension reforms. Flexible today, secure tomorrow? (Basingstoke, UK: Palgrave).

Iversen, T. and D. Soskice (2001) 'An asset theory of social policy preferences', American Political Science Review, 95, 4, 875-893.

Jæger, M. M. (2006) 'Welfare regimes and attitudes towards redistribution. The regime hypothesis revisited', European Sociological Review, 22, 2, 157-170.

Jensen, C. (2012) 'Labour market- versus life course-related social policies: understanding cross-programme differences', Journal of European Public Policy, 19, 2, 275-291.

Jensen, C. and E. Naumann (2016) 'Increasing pressures and support for public healthcare in Europe‘, Health Policy, 120, 6, 698-705.

Kitschelt, H. and P. Rehm (2006) 'New social risk and political preferences' in K.

Armingeon, G. Bonoli (eds.) The politics of post-industrial welfare states. Adapting post-war social policies to new social risks (London: Routledge).

Korpi, W. (1983) The democratic class struggle (London: Routledge).

Larsen, C. A. (2008) 'The institutional logic of welfare attitudes. How welfare regimes influence public support', Comparative Political Studies, 41, 2, 145-168.

Lepsius, M. R. (1990) 'Soziale Ungleichheit und Klassenstrukturen in der Bundesrepublik Deutschland“ in R. M. Lepsius (ed.) Ideen, Interessen und Institutionen (Opladen: Campus). Linos, K. and M. West (2003) 'Self interest, social beliefs, and attitudes to redistribution. Re addressing the Issue of Cross national Variation', European Sociological Review, 19, 4, $393-409$.

Lynch, J. and M. Myrskylä (2009) 'Always the third rail? Pension income and policy preferences in European democracies', Comparative Political Studies, 42, 8, 1068-1097. Marshall, T. H. (1950) Citizenship and social class (Cambridge: Cambridge University Press). 
Mau, S. (2004) 'Welfare regimes and the norms of social exchange', Current Sociology, 52, $1,53-74$.

Meltzer, A. H. and S. F. Richard (1981) ‘A rational theory of the size of government', Journal of political Economy, 89, 5, 914-927.

Myles, J. and P. Pierson (2001) 'The comparative political economy of pension reform‘ in P. Pierson (ed.) The New Politics of the Welfare State (Oxford: Oxford University Press). Naumann, E., M. Hess and L. Steinkopf (2015) ‘Die Alterung der Gesellschaft und der Generationenkonflikt in Europa/Aging Societies and Intergenerational Conflict in Europe‘, Zeitschrift für Soziologie, 44, 6, 426-446.

Oesch, D. (2006) Redrawing the class map. Stratification and institutions in Britain, Germany, Sweden and Switzerland (Basingstoke, UK: Palgrave).

Oesch, D. and J. R. Menes (2011) ‘Upgrading or polarization? Occupational change in Britain, Germany, Spain and Switzerland, 1990-2008‘, Socio-Economic Review, 9, 3, 503532.

Pierson, P. (2001a) 'Investigating the welfare state at century's end (Introduction)` in P. Pierson (ed.) The New Politics of the Welfare State (Oxford: Oxford University Press). Pierson, P. (ed.) (2001b) The New Politics of the Welfare State (Oxford: Oxford University Press).

Roller, E. (1995) 'The welfare state. The equality dimension` in O. Borre, E. Scarbrough (eds.) The scope of government (Oxford: Oxford University Press).

Rueda, D. (2005) 'Insider-outsider politics in industrialized democracies. The challenge to social democratic parties‘, American Political Science Review, 99, 1, 61-74.

Sainsbury, D. (1996) Gender, equality and welfare states (Cambridge: Cambridge University Press). 
Schwander, H. and S. Häusermann (2013) 'Who is in and who is out? A risk-based conceptualization of insiders and outsiders‘, Journal of European Social Policy, 23, 3, 248269.

Svallfors, S. (1997) 'Worlds of welfare and attitudes to redistribution. A comparison of eight western nations‘, European Sociological Review, 13, 3, 283-304.

Walker, A. (1999) 'Political participation and representation of older people in Europe` in A. Walker, G. Naegele (eds.) The politics of old age in Europe (Buckingham: Open University Press).

Weaver, R. K. (1986) 'The politics of blame avoidance', Journal of Public Policy, 6, 4, 371398.

Wendt, C., M. Mischke and M. Pfeifer (2011) Welfare states and public opinion. Perceptions of healthcare systems, family policy and benefits for the unemployed and poor in Europe (Cheltenham: Edward Elgar Publishing). 
Table 5.1 Support for a redistributive design of the public pension system, ESS 2008

\begin{tabular}{lllll}
\hline & & $\begin{array}{l}\text { Lower earners } \\
\text { should get larger } \\
\text { pensions }\end{array}$ & $\begin{array}{l}\text { High and low } \\
\text { earners should } \\
\text { get the same } \\
\text { pension }\end{array}$ & $\begin{array}{l}\text { Higher earners } \\
\text { should get larger } \\
\text { pensions }\end{array}$ \\
\cline { 2 - 5 } & (Both) & Support redistribution & Oppose \\
& & & $65 \%$ & $16 \%$ \\
Britain & $(83 \%)$ & $18 \%$ & $24 \%$ & $69 \%$ \\
\hline Germany & $(31 \%)$ & $7 \%$ & redistribution \\
\hline
\end{tabular}

Source: ESS 2008/09 - Question: "Some people say that higher earners should get larger old age pensions because they have paid in more. Others say that lower earners should get larger old age pensions because their needs are greater. Which of the three statements on this card comes closest to your view?” 
Table 5.2 Support for retrenchment of pension benefits, ESS 2008

\begin{tabular}{llllll}
\hline & $\begin{array}{l}\text { Government’s } \\
\text { responsibility } \\
\text { for pensions }\end{array}$ & $\begin{array}{l}\text { Mid-point } \\
\text { (status quo) }\end{array}$ & $\begin{array}{l}\text { Not } \\
\text { government's } \\
{[0-4]}\end{array}$ & $\begin{array}{l}\text { Average } \\
\text { sesponsibility }\end{array}$ & $\begin{array}{l}\text { Standard } \\
\text { error }\end{array}$ \\
& Retrenchment: Oppose & Support & Mean & SE \\
\hline Britain & $96 \%$ & $2 \%$ & $2 \%$ & 1.48 & {$[0.04]$} \\
Germany & $83 \%$ & $9 \%$ & $8 \%$ & 2.56 & {$[0.05]$} \\
\hline
\end{tabular}

Source: ESS 2008/09 
Table 5.3 Gender and age group differences in pension attitudes, ESS 2008

\begin{tabular}{llll}
\hline & \multicolumn{3}{c}{ Pensions specific attitudes } \\
Country & Group & retrenchment & redistrib \\
\hline \multirow{2}{*}{ (a) by gender } & & & \\
Britain & Women & $-0.19^{*}$ & -2.1 \\
Germany & Women & $-0.61^{*}$ & $+5.6^{*}$ \\
(b) by age groups & & \\
Britain & $15-30$ years & Ref.cat. & Ref.cat. \\
& $31-50$ years & $-0.25^{*}$ & +6.1 \\
& $51-65$ years & $-0.32^{*}$ & $+8.8^{*}$ \\
& $>65$ years & -0.16 & $+10.1^{*}$ \\
Germany & $15-30$ years & Ref.cat. & Ref.cat. \\
& 31-50 years & 0.06 & $-7.4^{*}$ \\
& $51-65$ years & 0.13 & $-9.4^{*}$ \\
& $>65$ years & 0.34 & $-12.2^{*}$
\end{tabular}

Note: * significant differences $(\mathrm{p}<0.05)$, Results are based on linear or logistic regression models for each country. 


\begin{tabular}{|c|c|c|c|}
\hline & \multicolumn{2}{|c|}{ Working-age population } & \multirow{2}{*}{$\begin{array}{c}\text { Retirement-age } \\
\text { population }\end{array}$} \\
\hline & Insiders & Outsiders & \\
\hline Highly-Skilled & $\begin{array}{c}\text { Capital } \\
\text { accumulators (CA) }\end{array}$ & $\begin{array}{c}\text { Socio-cultural } \\
\text { professionals (SCP) }\end{array}$ & \\
\hline Mixed & \multicolumn{2}{|c|}{ Mixed service functionaires (Mix) } & Retirees \\
\hline Low-skilled & $\begin{array}{c}\text { Blue-collar } \\
\text { workers (BC) }\end{array}$ & $\begin{array}{c}\text { Low-service } \\
\text { functionaires (LSF) }\end{array}$ & \\
\hline
\end{tabular}

Figure 5.1 Post-industrial class typology

Note: Categories from Häusermann (2010), mixed service functionaries are a residual category; our additional categories in italics. 


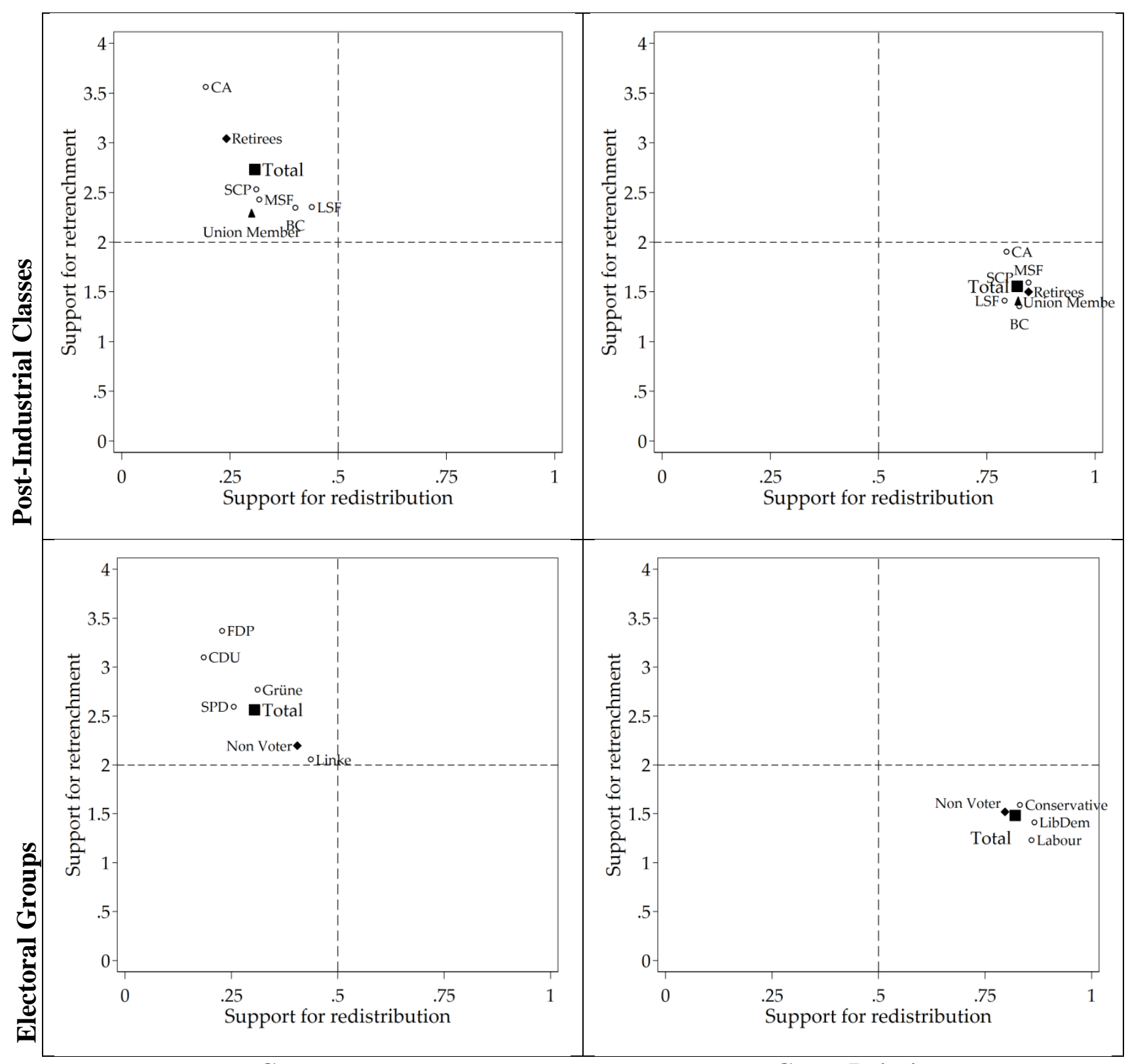

Germany

Great Britain

Figure 5.2 Support for retrenchment and support for redistribution among post-industrial classes and electoral groups - Predictions from logistic and linear regressions

Note: Support for retrenchment is measured on a 11-point scale ranging from 0 to 10. Support for redistribution shows the share of respondents supporting redistributive elements in the pension system 